\title{
REALIZM NAUKOWY WOBEC ZMIANY TEORII W NAUCE
}

\begin{abstract}
Streszczenie. Ważnym elementem współczesnej dyskusji pomiędzy realizmem i antyrealizmem naukowym jest próba nadania realistycznej interpretacji historycznemu faktowi zmiany teorii w nauce. Fakt ten według L. Laudana podważa nie tylko najważniejszy argument na rzecz realizmu naukowego, ale i najważniejsze tezy tego stanowiska. Argumentem kwestionowanym przez Laudana jest twierdzenie H. Putnama, że ogromny sukces nauki w przewidywaniu zjawisk i rozwijaniu nowych technologii świadczy przynajmniej o aproksymacyjnej prawdziwości teorii naukowych. Laudan wykazuje jednak fakty z historii nauki, gdy odnoszące sukces teorie okazywały się z biegiem czasu fałszywe. Powiązany z tym argument przeciwko realizmowi, zwany pesymistyczną indukcją (PI), głosi, iż skoro przeszłe teorie, które odniosły sukces, okazywały się fałszywe z perspektywy nowszych, to także obecne odnoszące sukces teorie mogą okazać się w przyszłości fałszywe. Podważa to tezę odnośnie związku sukcesu teorii z jej aproksymacyjną prawdziwością. Ważnym wyzwaniem dla realizmu naukowego staje się zatem uzgodnienie jego tez z faktem zmiany teorii w nauce. Najbardziej znaczących rozwiązań tego problemu dostarcza realizm strukturalny zaproponowany przez J. Worralla i semirealizm A. Chakrawarttiego. Oba stanowiska przyjmują tę samą strategię obrony realizmu, zwaną divide et impera, uznającą, że nie całe teorie, lecz tylko ich fragmenty bezpośrednio związane z sukcesem spełniają tezy realizmu. Realizm naukowy w tych sformułowaniach zostaje w znacznym stopniu ograniczony i osłabiony. Celem artykułu jest przedstawienie tych rozwiązań i pokazanie z jednej strony realistycznych odpowiedzi na argument PI, jakich dostarczają te stanowiska, z drugiej ograniczeń, jakie z nich wynikają dla realizmu naukowego. Osłabiona wersja realizmu, jaką one proponują, również nie jest wolna od istotnych trudności, na jakie musi odpowiedzieć zarówno realizm strukturalny, jak i semirealizm. Identyfikacja tych trudności może stanowić wskazówkę dla dalszego rozwoju stanowiska realistycznego.
\end{abstract}

Słowa kluczowe: realizm naukowy; realizm konwergentny; realizm strukturalny; semirealizm; aproksymacyjna prawda; strategia divide et impera

1. Wstęp. 2. Krytyka realizmu konwergentnego i jego ewolucja pod wpływem argumentu pesymistycznej indukcji. 3. Realizm strukturalny i semirealizm jako odpowiedź na argument ze zmiany teorii w nauce. 4. Trudności realizmu strukturalnego i kierunki jego rozwoju. 5. Zakończenie. 


\section{WSTĘP}

W ostatnich kilku dekadach główna oś sporu realizmu naukowego $\mathrm{z}$ antyrealizmem jest wyznaczona przez dwa podstawowe argumenty wysuwane przez opozycyjne strony: argument na rzecz realizmu, sformułowany przez H. Putnama, odwołujący się do sukcesu nauki, zwany argumentem $\mathrm{z}$ braku cudów (NMA) oraz argument przeciw realizmowi, odwołujący się do historycznych faktów radykalnej zmiany teorii w nauce. Argument antyrealistyczny oparty na fakcie, że teorie uznawane w przeszłości za prawdziwe, okazywały się $\mathrm{z}$ biegiem czasu fałszywe, nosi nazwę pesymistycznej indukcji (PI). Podważa on wiarygodność współczesnych teorii odnoszących sukces, a przez to argument MNA i cały realizm naukowy. Wyzwaniem dla realizmu naukowego stało się zatem pogodzenie ogromnego sukcesu współczesnych teorii naukowych z faktem, że przeszłe teorie, również odnoszące sukces, okazywały się z perspektywy czasu fałszywe.

$\mathrm{W}$ artykule zostaną przedstawione najbardziej znaczące stanowiska dostarczające odpowiedzi na to wyzwanie, czyli realizm strukturalny i semirealizm. Omówienie możliwości obrony tez realizmu naukowego $\mathrm{w}$ ramach tych stanowisk, jak również dokonujące się w nich osłabienie i zawężenie realizmu, stanowi główną treść artykułu. Następująca w końcowej części analiza trudności, na jakie napotykają te stanowiska, pozwoli wskazać zagadnienia, które pozostają nadal otwarte i wymagają dalszego opracowania z perspektywy realizmu naukowego.

\section{KRYTYKA REALIZMU KONWERGENTNEGO I JEGO EWOLUCJA POD WPEYWEM ARGUMENTU PESYMISTYCZNEJ INDUKCJI}

Punktem wyjścia współczesnej dyskusji był realizm naukowy w wersji zwanej realizmem konwergentnym, który przyjmuje, że teorie naukowe, które odniosły sukces empiryczny, są prawdziwe lub co najmniej aproksymacyjnie prawdziwe, a obecne teorie są bliższe 
prawdy, niż ich poprzedniczki. Twierdzi też, że terminy teoretyczne dojrzałych teorii mają realne odniesienia, a ich twierdzenia są zachowane w następujących po nich teoriach, jeśli nie w tej samej formie, to przynajmniej jako graniczne przypadki. Głosi też często, że nowsze teorie (w danej dziedzinie) wyjaśniają sukces swoich poprzedniczek. Aby wyjaśnić, jak kolejne teorie coraz bardziej zbliżają się do prawdy, zwolennicy tego stanowiska odwołują się do pojęcia aproksymacyjnej prawdy, która bywa różnie rozumiana, o czym będzie mowa w dalszej części rozważań.

Realizm konwergentny był formułowany przez różnych autorów na nieco inne sposoby, wyrażał on jednak zawsze ogólną tezę realizmu naukowego, że nauka bada i opisuje świat, jaki istnieje niezależnie od ludzkiego poznania i rezultatem tego poznania jest prawdziwa lub aproksymacyjnie prawdziwa wiedza o świecie. Obserwowany rozwój nauki, dzięki stosowanym w niej metodom poznawczym, przebiega w kierunku coraz bardziej prawdziwych teorii na temat rzeczywistości ${ }^{1}$.

Kluczowym obecnie argumentem na rzecz realizmu naukowego jest wysunięty przez Hilarego Putnama argument z sukcesu nauki. Uznaje on realizm naukowy za najlepsze wyjaśnienie tego sukcesu. Jak mówi autor „realizm jest jedyną filozofią, która nie czyni sukcesu nauki cudem"2. Jest to obecnie najważniejszy argument na rzecz realizmu naukowego. Łączy on sukces teorii naukowej z jej aproksymacyjną prawdziwością. Jeśli sukces, jaki osiągają teorie naukowe w przewidywaniu zjawisk i rozwoju nowych technologii, jest najlepiej wyjaśniany przez założenie, że teorie naukowe dostarczają prawdziwej wiedzy o świecie i postulowane przez nie obiekty realnie

1 Jedno ze sformułowań podaje np. R.N. Boyd, On the Current Status of the Issue of Scientific Realism, Erkenntnis 19(1983)1-3, 45-90, 45.

2 H. Putnam, What is Mathematical Truth?, w: Mathematics, Matter and Method, Collected Papers, Vol. 2, Cambridge 1975, 60-78, 73. 
istnieją, to skoro sukces nauki jest faktem, realizm naukowy jest przypuszczalnie prawdziwy.

Ta ogólna idea od początku budziła wiele wątpliwości, jak też wymagała dalszych uściśleń. Bardziej precyzyjne sformułowanie tego argumentu wymagało doprecyzowania pojęcia sukcesu nauki oraz wyróżnienia teorii naukowych, do których należy odnosić tezy realizmu. Nie każdą bowiem teorię pojawiającą się w nauce należy uważać za prawdziwą lub aproksymacyjnie prawdziwą. W rezultacie przyjęło się, że sukces teorii rozumiany jest w sensie sukcesu predykcyjnego, czyli sukcesu w formułowania skutecznych nowatorskich prognoz. Tylko do teorii, które odniosły tego rodzaju sukces należy, zdaniem Alana Musgrave'a, odnosić tezy realizmu naukowego ${ }^{3}$. Teorie te określane są jako „dojrzałe teorie” lub „najlepsze teorie”.

Bardziej formalnie NMA ujmowany jest jako rodzaj wnioskowania do najlepszego wyjaśniania. Zgodnie z tą zasadą, jak pisze Adam Grobler, „hipotezę, która dostarcza najlepszych (spośród dostępnych) wyjaśnień zjawisk rozpatrywanej dziedziny, należy uznać za przypuszczalnie prawdziwą"4. Zarówno przeciwko samemu wnioskowaniu do najlepszego wyjaśnienia, jak i takiemu ujęciu NMA, wysunięto liczne zastrzeżenia z pozycji antyrealistycznych.

Np. Bastiaan C. van Fraassen twierdził, że sukces nauki nie potrzebuje żadnego szczególnego uzasadnienia ${ }^{5}$. Teorie naukowe są, według niego, poddane metodologicznej selekcji na wzór selekcji adaptacyjnej i jedynie teorie, które mają znaczny sukces empiryczny, mogą przetrwać w nauce, podobnie jak tylko dobrze ewolucyjnie przystosowane organizmy mogą przetrwać $\mathrm{w}$ przyrodzie. Zdaniem van Fraassena, sens, w jakim w tym kontekście sukces teorii może być rozumiany, to sukces empiryczny, polegający na skutecznym

3 A. Musgrave, Ostateczny argument za realizmem naukowym, tłum. z ang. M. Kotowski, w: Spór o realizm naukowy, red. M. Kotowski, Wrocław 2018, 89-116, 93.

4 A. Grobler, Prawda a względność, Kraków 2000, 110.

5 B.C. van Fraassen, The Scientific Image, Oxford 1980, 40. 
przewidywaniu całkiem nowych kategorii zjawisk, czyli sukces predykcyjny. Sukces taki dowodzi jednak tylko empirycznej adekwatności teorii, nie oznacza zaś, że teoria jest prawdziwa lub aproksymacyjnie prawdziwa. Najlepsze teorie naukowe, jego zdaniem, odniosły tego rodzaju sukces, ale są one prawdziwe jedynie odnośnie do faktów obserwacyjnych, nie są natomiast prawdziwe lub aproksymacyjnie prawdziwe odnośnie do nieobserwowalnych obiektów postulowanych przez teorie.

$\mathrm{Z}$ formalnego punktu widzenia zasada wnioskowania do najlepszego wyjaśnienia opiera się na wnioskowaniu abdukcyjnym ${ }^{6}$. Niekonkluzywność abdukcji i jej trudności stały się początkiem długiej i bogatej dyskusji toczonej wokół bayesiańskiego sformułowania NMA. Np. Colin Howson przedstawił i rozwinął bayesowską rekonstrukcję NMA, wykazując, że jest to argument wewnętrznie sprzeczny ${ }^{7}$. Przeciwko takiemu stanowisku argumentują jednak np. J. Worrall ${ }^{8}$ i S. Psillos 9 , którzy twierdzą, że rekonstrukcja, jaką proponuje Howson, nie jest odpowiednia dla NMA. Ten wątek dyskusji, choć interesujący z formalnego punktu widzenia, nie dotyczy jednak bezpośrednio przedmiotu dyskutowanego w tym artykule.

Największy wpływ na dalszy bieg omawianej dyskusji wywarła krytyka argumentu NMA przedstawiona przez Larry'ego Laudana ${ }^{10}$. Zapoczątkowała ona stopniową, ale wyraźną ewolucję realizmu konwergentnego, która doprowadziła do radykalnego ograniczenia tez realizmu naukowego w kolejnych jego sformułowaniach. Laudan odrzuca w niej główne tezy realizmu. Kwestionuje, że dojrzałe teorie

6 S. Psillos, Scientific Realism: How Science Tracks Truth, London 1999, 203-215.

7 Por. C. Howson, Hume's Problem: Induction and the Justification of Belief, Oxford 2000, jak również odpowiedź na przedstawione mu zarzuty w: C. Howson, Exhuming the No Miracles Argument, Analysis 73(2013)2, 205-211.

8 J. Worrall, Miracles and Models: Why Reports of the Death of Structural Realism May Be Exaggerated, Royal Institute of Philosophy Supplements 61(2007)10, 125-154.

9 S. Psillos, Knowing the Structure of Nature, New York 2009.

10 L. Laudan, Obalenie realizmu konwergentnego, tłum. z ang. M. Kotowski, w: Spór o realizm naukowy, dz. cyt., 29-65. 
naukowe są na ogół aproksymacyjnie prawdziwe, a teorie nowsze w danej dziedzinie są bliższe prawdy, niż teorie starsze, jak te $\dot{z}, \dot{z} e$ obserwacyjne oraz teoretyczne pojęcia, które występują w teoriach nauk dojrzałych, posiadają odniesienie przedmiotowe. Ponadto poddaje w wątpliwość twierdzenie realizmu konwergentnego, że w nauce dojrzałej przyszłe teorie będą zachowywać teoretyczne relacje i postulowane przedmioty odniesienia teorii wcześniejszych. Kwestionuje też argument Putnama, że tak rozumiany realizm dostarcza najlepszego wyjaśnienia sukcesu nauki11.

Odwołując się do faktów z historii nauki, Laudan pokazuje, że w historii nauki jest wiele teorii, które pomimo że odniosły sukces empiryczny, okazały się fałszywe z perspektywy czasu, a postulowane przez nie nieobserwowalne obiekty (jak np. flogiston lub eter) zostały uznane za nieistniejące. Przedstawia całą listę takich teorii, które mają przeczyć tezom realizmu ${ }^{12}$. Sukces teorii nie przesądza, zdaniem Laudana, ani o jej prawdziwości, ani o istnieniu postulowanych przez nią obiektów teoretycznych.

Fakty, które przytacza Laudan, są podstawą dla mocnego kontrargumentu przeciwko realizmowi, jakim jest pesymistyczna indukcja (PI), nazywana też pesymistyczną meta-indukcją (w skrócie PMI). Argument ten głosi, że jeśli przeszłe teorie, które w swoim czasie odnosiły sukces (także predykcyjny), okazywały się wraz z rozwojem nauki fałszywe, to najlepsze współczesne teorie odnoszące taki rodzaj sukcesu, mogą również okazać się w przyszłości fałszywe. Sukces predykcyjny teorii, w kontekście radykalnej zmiany teorii, nie jest, w myśl PI, argumentem na rzecz jej prawdziwości. Ten kontrargument stanowi dla realizmu poważne wyzwanie. Realista naukowy musi wyjaśnić zmiany teorii naukowych, jednocześnie zachowując związek prawdziwości teorii naukowych i realność postulowanych

11 Tamże, 31.

12 Tzw. Lista Laudana. Por. tamże, 35-47. 
przez nie obiektów z ich sukcesem predykcyjnym, inaczej podstawowy argument realizmu traci swą siłę.

Odpowiedzią ze strony realizmu na argument PI są między innymi formalne próby podważenia adekwatności stosowania PI w stosunku do współczesnych teorii. Np. Ludwig Fahrbach ${ }^{13}$ wskazuje, że ogromny rozwój nauki od początku drugiej połowy XX wieku sprawia, iż współczesne i przeszłe teorie, ze względu na ich empiryczne ugruntowanie, nie mogą być traktowane podobnie, nie ma zatem podstaw do indukcyjnych wniosków w sensie PI. Twierdzi on, że wniosek PI jest niepoprawny, gdyż był wyprowadzony na podstawie nieuprawnionej projekcji faktów dotyczących przeszłych teorii na fakty o teoriach współczesnych i przyszłych. Pogląd, że współczesne teorie należy traktować w inny sposób niż przeszłe, podzielają także np. Gerald Doppelt ${ }^{14}$, Juha Saatsi ${ }^{15}$, Seungbae Park ${ }^{16}$ i inni.

Odwrotnie twierdzi K. Brad Wray ${ }^{17}$, broniący PI. Dowodzi on, że z perspektywy przyszłości współczesne teorie okażą się tak samo mało uzasadnione, jak przeszłe z perspektywy nauki współczesnej. Zatem przeszłe i obecne teorie należy traktować tak samo, co czyni argument PI poprawnym. Podobnych argumentów używa także P. Kyle Stanford ${ }^{18}$.

Te i podobne próby wykazania słabości metodologicznej argumentu PI są ważne $z$ tego względu, że skłaniają do analizy metod powoływania się na historię nauki w filozoficznej refleksji nad

13 L. Fahrbach, How the Growth of Science Ends Theory Change, Synthese 180(2011)2, 139-155.

14 G. Doppelt, From Standard Scientific Realism and Structural Realism to Best Current Theory Realism, Journal for General Philosophy of Science 42(2011)2, 295-316.

15 J. Saatsi, Grasping at Realist Straws, Metascience 18(2009)3, 355-362.

16 S. Park, On Treating Past and Present Scientific Theories Differently, Kriterion 31(2017)1, 63-76.

17 K.B. Wray, Pessimistic Induction and the Exponential Growth of Science Reassessed, Synthese 190(2013)18, 4321-4330.

18 P.K. Stanford, Catastrophism, Uniformitarianism, and a Scientific Realism Debate. That Makes a Difference, Philosophy of Science 82(2015)5, 867-878. 
rozwojem nauki. Wskazują, że przejście pomiędzy historią i filozofią nauki nie jest jednoznaczne i wymaga dodatkowej refleksji. Pomijają one jednak merytoryczny aspekt sporu.

Argument PI ujawnił potrzebę określenia kryteriów, jakie spełniać mają teorie, o których już była wzmianka, a które bierze się pod uwagę w dyskusji nad realizmem naukowym. Według realistów takich jak John Worrall ${ }^{19}$ i Stathis Psillos ${ }^{20}$ nie są to wszystkie teorie, jakie odniosły sukces empiryczny, ale są to tzw. dojrzałe teorie, jak np. w fizyce teoria względności czy teoria kwantowa. Wyróżnikiem dojrzałej teorii jest dodatkowo, obok sukcesu predykcyjnego, stabilność teorii w czasie oraz wobec testów empirycznych, jak też ugruntowanie w odniesieniu do innych teorii dobrze potwierdzonych zgodnie z metodologią danej dziedziny. Ograniczenia te nie eliminują jednak niektórych teorii, które choć spełniały warunki sukcesu dojrzałych teorii, to zostały odrzucone.

Istnienie takich teorii stanowi duży problem, gdyż jak dowodzi Timothy D. Lyons, wnioskowanie na podstawie listy Laudana bądź innej listy teorii, które odniosły sukces, lecz zostały odrzucone, ma raczej status logiczny wnioskowania modus tollens, niż wnioskowania indukcyjnego $\mathrm{z}$ fałszywości przeszłych teorii o fałszywości współczesnych. Zatem wystarczą pojedyncze kontrprzykłady, aby uchylić ogólny związek pomiędzy sukcesem teorii a jej aproksymacyjną prawdziwością ${ }^{21}$.

Dużą trudność dla realizmu konwergentnego stanowi też podstawowe pojęcie aproksymacyjnej prawdziwości teorii, które w tych rozważaniach jest rozumiane intuicyjnie. Próby określenia ilościowego przybliżonej prawdziwości czy prawdopodobieństwa teorii

19 J. Worrall, Realizm strukturalny. To co najlepsze z dwóch światów, tłum. z ang. M. Kotowski w: Spór o realizm naukowy, dz.cyt., 162-163.

20 S. Psillos, Scientific Realism: How Science Tracks Truth, dz. cyt., 105-108.

21 Por. D.T. Lyons, Four Challenges to Epistemic Scientific Realism - and the Socratic Alternative, Spontaneous Generations: A Journal for the History and Philosophy of Science 9(2018)1, 146. 
w sensie ich podobieństwa do prawdy, zapoczątkowane przez Poppera i wciąż podejmowane, nie przyniosły powszechnie uznanych rezultatów. Dla uściślenia pojęcia aproksymacyjnej prawdy tacy autorzy, jak np. John Worrall, Robert Boyd i Anjan Chakravartty ${ }^{22}$, wskazują pewne jakościowe warunki tego, kiedy jedna teoria jest bardziej aproksymacyjnie prawdziwa od drugiej. Daje to podstawę dla porównania następujących po sobie teorii w aspekcie zbliżania się do prawdy w procesie rozwoju nauki. Jest to jednak relatywne określenie aproksymacyjnej prawdziwości. Argument PI skłonił do głębszej refleksji metodologicznej nad argumentem z sukcesu nauki i przyczynił się do większego sformalizowania postaci realizmu naukowego, uściślenia jego pojęć i zawężenia jego zakresu do pewnej tylko grupy teorii dojrzałych.

Powszechnie przyjmowana obecnie strategia obrony realizmu opiera się na założeniu, że odrzucone teorie, choć nie są w całości aproksymacyjnie prawdziwe, to zawierają pewne elementy, które można wyodrębnić jako bezpośrednio odpowiedzialne za sukces predykcyjny teorii i które można w świetle nowszych teorii uznać za aproksymacyjnie prawdziwe. Te fragmenty zostają $\mathrm{w}$ jakiejś formie zachowane w teoriach następnych, jako kumulatywny składnik wiedzy o zjawiskach. Ta strategia obrony realizmu naukowego określana jest jako strategia divide et impera ${ }^{23}$. Strategia ta prowadzi do formułowania bardziej ograniczonych wersji realizmu naukowego zwanych realizmem selektywnym, częściowym lub rozwiniętym (deployment realism) ${ }^{24}$.

Głosi ona, że tylko te fragmenty teorii, które są bezpośrednio odpowiedzialne za jej sukces predykcyjny, mogą być interpretowane

22 A. Chakravartty, Truth and Representation in Science: Two Inspirations from Art, w: Beyond Mimesis and Convention: Representation in Art and Science, red. R. Frigg, M. Hunter, Dordrecht 2010, 33-50.

23 S. Psillos, Scientific Realism: How Science Tracks Truth, dz. cyt., 108.

24 P. Vickers, Understanding the Selective Realist Defence Against the PMI, Synthese 194(2017)9, 3221-3232. 
realistycznie, jako aproksymacyjnie prawdziwe tezy o zjawiskach. Problemem dla tej strategii jest to, że nie wiemy, które fragmenty teorii są aproksymacyjnie prawdziwe, dopóki nowa teoria nie odsłoni ich kumulatywnego charakteru. Kumulatywne elementy teorii można dokładnie wyodrębnić dopiero z perspektywy jej następczyni. Jako praktyczne kryterium oceny przybliżonej prawdziwości teorii (z perspektywy jej własnych osiągnięć) nadal pozostaje znaczący sukces predykcyjny, który ona generuje. Nie wiadomo jednak, który z jej składników zawiera owo „ziarno prawdy”, a który okaże się fałszywy. Dopiero sformułowanie kolejnej teorii, która odniesie sukces, pozwoli wyodrębnić części, które w jej świetle okażą się prawdziwe. Na czym jednak opierać ma się założenie, że nowsza teoria jest aproksymacyjnie prawdziwa i że zgodność z nią może być kryterium aproksymacyjnej prawdziwości elementów poprzedniczki, jeśli nie ma kolejnej teorii?

Argument PI przyczynił się do uściślenia, zawężenia, przeformulowania i osłabienia tez realizmu ${ }^{25}$. Zakres teorii, jakie realizm bierze pod uwagę, został ograniczony do teorii dojrzałych, które rozumiane są najczęściej jako posiadające znaczny sukces predykcyjny. Warunek prawdziwości lub aproksymacyjnej prawdziwości, odnoszony do teorii naukowych, rozumianych jako całość, został ograniczony jedynie do wybranych elementów, bezpośrednio odpowiedzialnych za sukces predykcyjny teorii. Elementy te, zgodnie ze strategią divide et impera, stanowią kumulatywną część nauki. Podobnie, nie wszystkie terminy teoretyczne mają swoje realne odniesienia, a tylko te, które są postulowane przez wyodrębnione komponenty teorii odpowiedzialne za jej sukces predykcyjny ${ }^{26}$.

25 Por. M. Kotowski, O rozwoju realizmu naukowego jako selektywnego sceptycyzmu, Filozofia Nauki 22(2014)3, 105-123 oraz Tenże, Realizm zreformowany. Filozofia Iana Hackinga a spór o status poznawczy wiedzy naukowej, Wrocław 2016.

26 A. Chakravartty, Semirealism, Studies in History and Philosophy of Science 29(1998)3, 396. 


\section{REALIZM STRUKTURALNY I SEMIREALIZM JAKO ODPOWIEDŹ NA ARGUMENT ZE ZMIANY TEORII W NAUCE}

Najbardziej znaczących odpowiedzi na wyzwanie, jakie stanowią dla realizmu naukowego radykalne zmiany teorii, dostarczaja zaproponowany przez Johna Worrala ${ }^{27}$ realizm strukturalny oraz semirealizm A. Chakravartty'ego ${ }^{28}$, będące syntezą realizmu naukowego i argumentu $\mathrm{PI}^{29}$.

Worrall przyjmuje, że dla obrony realizmu należy wykazać, iż pomimo radykalnych zmian teorii rozwój nauki jest zasadniczo kumulatywny. Aproksymacyjnie prawdziwy element teorii $\mathrm{T}_{1}$ powinien być zachowany nie tylko w następującej po niej teorii $\mathrm{T}_{2}$, ale i w kolejnej teorii $T_{3}$, zastępującej z czasem teorię $T_{2}$. Te powiązane $z$ sukcesem predykcyjnym elementy poprzedniczki, które zostają zachowane w jej następczyni, można uznać za aproksymacyjnie prawdziwe.

Worrall przyjmuje strategię divide et impera, uznając, że elementy teorii, które są odpowiedzialne za jej sukces predykcyjny, są aproksymacyjnie prawdziwe i jako takie zostały zachowane w następnych po niej teoriach. Warunek ten wyraża kumulatywny charakter rozwoju wiedzy, w którym nowe teorie przejmują prawdziwe części swoich poprzedniczek, odrzucając fałszywe ${ }^{30}$. Stąd zachowanie elementów poprzedniczki w następnej teorii staje się kryterium uznania ich za aproksymacyjnie prawdziwe. Strategia ta pozwala Worrallowi skutecznie bronić realizmu naukowego.

Pojęcie aproksymacyjnej prawdziwości, pomimo wprowadzonych uściśleń, nadal pozostaje intuicyjne i nie do końca jasne. Można pytać:

27 J. Worrall, Realizm strukturalny. To co najlepsze z dwóch światów, tłum. z ang. M. Kotowski w: Spór o realizm naukowy, dz. cyt., 145-175.

28 A. Chakravartty, Semirealism, dz. cyt.

29 Stanowiska te mają swoich kontynuatorów i są rozwijane, ale w tym artykule ograniczę się tylko do wymienionych dwu autorów. Rozwój stanowisk nie wpłynął bowiem znacząco na zmianę podejmowanych tu kwestii.

30 J. Worrall, Realizm strukturalny. To co najlepsze z dwóch światów, dz. cyt., 153-154. 
w jakim sensie teoria Newtona jest przybliżeniem teorii względności Einsteina? Np. STW Einsteina nie jest prostym rozszerzeniem teorii Newtona, choć przejmuje sukces empiryczny teorii Newtona. Pomimo że przy przejściu od teorii Newtona do teorii Einsteina empiryczna treść teorii okazała się kumulatywna, to teoretyczna treść obu teorii nie jest taka, np. zgodnie z teorią Newtona, czas jest absolutny, a masa ciał jest stała ze względu na prędkość, natomiast według teorii Einsteina, czas jest względny, a masa ciał rośnie wraz z ich prędkością. Jak głosi Thomas Kuhn, następujące po sobie teorie są niewspólmierne i nie zachodzi teoretyczna ciągłość między nimi. Dają one odmienne obrazy świata, których nie sposób porównać, ich ontologie są całkowicie różne. Nawet jeśli teorie te operują tymi samymi terminami, to terminy te mają inne znaczenia. Kuhn przytacza na to wiele przykładów ${ }^{31}$.

Van Fraassen twierdzi, że w wypadku radykalnej zmiany teorii kumulatywna jest tylko treść empiryczna teorii. Treść teoretyczna natomiast, wraz z postulatami odnośnie istnienia nieobserwowalnych obiektów i ich własności, ulega zmianie wraz ze zmianą teorii ${ }^{32}$.

Worrall wykazuje jednak, że w przypadku radykalnej zmiany dojrzałych teorii nie tylko treść empiryczna wcześniejszej teorii $\mathrm{T}_{1}$ jest zachowana $\mathrm{w}$ nowej teorii $\mathrm{T}_{2}$, ale też istotny element treści teoretycznej, jaki stanowią matematyczne równania teorii. Równania te, zdaniem Worralla, reprezentują realne, podstawowe struktury zjawisk. Rozwija on ideę Poincarego, że struktura matematyczna dojrzałych teorii naukowych odzwierciedla realne przyczynowe struktury rzeczywistości. Zmiana teorii nie podważa struktury samych relacji przyczynowych i odzwierciedlających je równań, choć może podważyć ontologię, w jakiej je interpretowano.

31 T.S. Kuhn, Struktura rewolucji naukowych, tłum. z ang. H. Ostromęcka, Warszawa 2001, 257-262. Szerokie omówienie problemu niewspółmierności można znaleźć np. w: K. Jodkowski, Teza o niewspółmierności w ujęciu Thomasa Kuhna i Paula Feyerabenda, Lublin 1984.

32 B.C. van Fraassen, The Scientific Image, dz. cyt., 40. 
Przykładem swoich rozważań Worral czyni przypadek przejścia w optyce pomiędzy teorią światła Fresnela i teorią Maxwella. Teoria Fresnela należy do wskazanych przez Laudana teorii, które odniosły sukces predykcyjny, ale zostały odrzucone $z$ czasem jako fałszywe. Zgodnie z teorią Fresnela światło jest falą poprzeczną, rozchodzącą się $\mathrm{w}$ eterze. Teoria ta odniosła sukces empiryczny i predykcyjny, pomimo że zakładała istnienie drgającego mechanicznego eteru, które zostało z czasem zanegowane. Teorię Fresnela zastąpiła teoria Maxwella, zgodnie z którą światło jest poprzeczną falą elektromagnetyczną. Obie teorie różnią się odnośnie do natury światła i w tym aspekcie są sprzeczne. Jeśli jednak ograniczymy się do poziomu niezinterpretowanych równań matematycznych, to zachodzi zgodność pomiędzy równaniami Fresnela i odpowiadającymi im równaniami wyprowadzonymi $z$ teorii Maxwella ${ }^{33}$. Formalizm matematyczny Fresnela pozwala na prawdziwe przewidywania zjawisk, gdyż, zdaniem Worralla, odzwierciedla realne, nieobserwowalne struktury rzeczywistości. Pozostaje on niezmieniony przy przejściu od jednej dojrzałej teorii do drugiej, pomimo że jego interpretacja ulega znaczącej zmianie. Zbieżność matematycznej postaci równań jest dla Worralla podstawowym argumentem na rzecz postulowania pewnej formy kumulatywizmu w nauce. To, co jest kumulatywne obok treści empirycznej, to struktury matematyczne reprezentujące realne, choć nieobserwowalne struktury rzeczywistości. Te struktury formalne to jedyne, co możemy poznać o rzeczywistości. Ich ontologiczna interpretacja zmienia się wraz ze zmianą teorii. Odzwierciedlają one realne choć nieobserwowalne relacje przyczynowe, zachodzące w zjawiskach.

Przypadek przejścia od teorii Fresnela do teorii Maxwella nie jest reprezentatywny dla sytuacji zmiany teorii w nauce. Worrall przyjmuje jednak, że o zachowaniu równań można mówić także, gdy pomiędzy równaniami teorii $\mathrm{T}_{1} \mathrm{i}$ równaniami jej następczyni

33 J. Worrall, Realizm strukturalny. To co najlepsze z dwóch światów, dz. cyt., 169. 
$\mathrm{T}_{2}$ zachodzi graniczna zbieżność $\mathrm{w}$ sensie przyjmowanej w fizyce zasady korespondencji3 ${ }^{4}$.

Relacja korespondencji zachodzi, gdy równania starszej teorii są granicznymi przypadkami odpowiednich równań nowszej teorii, jak np. w wypadku równań teorii Newtona i teorii relatywistycznej Einsteina. Jednak w takim wypadku równania starej teorii nie są odtworzone w nowej. Jak twierdzi Chakravartty, oba układy równań mogą być nawet ze sobą sprzeczne, ponieważ w wyniku bardziej precyzyjnych pomiarów i szerszego zakresu zjawisk nowe teorie dodają do równań nowe terminy, aby lepiej uchwycić złożoność badanych zjawisk. Jednak równania nowszej teorii przyjmują postać równań starej, jeśli określona wielkość nowej teorii przyjmuje graniczną wartość. Są one szczególnym przypadkiem równań nowej teorii o całkiem innej postaci ${ }^{35}$.

Worrall uznaje, że taka semikumulatywność w sensie relacji korespondencji jest istotnym rodzajem kumulatywności i odpowiada podstawowej realistycznej idei, że sukces predykcyjny dojrzałych teorii nie pozostaje bez związku $\mathrm{z}$ ich prawdziwością. Jeśli teoria $\mathrm{T}_{1}$ może być rozważana $\mathrm{w}$ jakimś zakresie jako graniczny przypadek teorii $\mathrm{T}_{2}$, wtedy teoria $\mathrm{T}_{1} \mathrm{w}$ tym zakresie aproksymuje teorię $\mathrm{T}_{2}$.

Według strukturalizmu Worralla aproksymacyjna prawdziwość odnosi się jedynie do formalizmu matematycznego, który opisuje relacyjne struktury rzeczywistości i który stanowi jedyną prawdziwą wiedzę o rzeczywistości. Każda teoria dodaje do owych struktur matematycznych właściwą dla siebie ontologię, która nie jest zachowywana przy zmianie teorii (np. przy przejściu od teorii Fresnela do teorii Maxwella, od teorii Newtona do teorii Einsteina itp.) Według realizmu strukturalnego teorie naukowe nie mówią niczego

34 Por. H. Post, Correspondence, invariance and heuristics, Studies in History and Philosophy of Science 2(1971)3, 213-255.

35 A. Chakravartty, Semirealism, dz .cyt., 399. 
wiążącego o naturze obiektów ukrytych za tą strukturą. Natura i własności nieobserwowanych obiektów pozostają nieznane.

Realizm strukturalny broni więc bardzo ograniczonej formy realizmu naukowego. Wiedza pewna to minimalna wiedza, jakiej dostarcza formalizm matematyczny teorii odzwierciedlający obserwowane empirycznie relacje przyczynowe. Teorie naukowe moga jedyne ujawnić strukturę nieobserwowalnego świata na podstawie własnej struktury matematycznej. Ich równania matematyczne, które zostają zachowane po zmianie teorii, wyrażają rzeczywiste relacje między bytami, o których nie wiemy nic więcej, jak tylko to, że pozostają one w tych matematycznie wyrażonych relacjach. Różne ontologie (a zatem różne interpretacje teoretyczne) mogą odpowiadać tej samej strukturze matematycznej, nie ma jednak podstaw, aby jedną $z$ nich uznać za lepiej uzasadnioną niż inne. $Z$ drugiej strony realizm strukturalny pokazuje i podkreśla wartość poznawczą samych takich struktur, nawet przy niepewności co do poprawności ich interpretacji. Wiedza na poziomie strukturalnym jest możliwa także wtedy, gdy pozostaje nierozpoznana ontologiczna natura zjawisk.

Jako rozwinięcie i dopełnienie realizmu strukturalnego o problematykę przedmiotów teoretycznych, które realizm strukturalny usuwa poza granicę poznania, A. Chakravartty proponuje stanowisko, które określa jako semirealizm. Dowodzi, że przyjęcie realizmu strukturalnego ma konsekwencje odnośnie do istnienia i własności obiektów teoretycznych wyznaczających relacje przyczynowe odzwierciedlane przez równania. Występowanie relacji pociąga za sobą wniosek, że jakieś argumenty tworzą te relacje. Wykazuje on, że „wiedza o strukturach implikuje wiedzę zarówno o istnieniu bytów spełniających te struktury, jak i o ich niektórych właściwościach detekcyjnych" 36 .

Chakravartty, argumentując na rzecz realności przedmiotów charakteryzowanych przez własności detekcyjne, nawiązuje do

36 A. Chakravartty, Semirealism, dz. cyt., 392. 
stanowiska I. Hackinga, który utrzymuje, że własności przyczynowe nieobserwowalnych obiektów teoretycznych ujawniające się w trakcie empirycznej manipulacji tymi obiektami, są dowodem ich realnego istnienia. Gdy jakieś przedmioty teoretyczne zostaną empirycznie wykryte w ramach jednej teorii, zostają zachowane także w kolejnych teoriach po niej następujących. Np. termin „elektron”, występujący w teoriach Thomsona, Lorentza, Milikana, Bohra, odnosi się w każdej z tych teorii do tej samej realnej cząstki, mimo że jego teoretyczna treść ulegała zmianie od teorii do teorii ${ }^{37}$.

Chakravartty uznaje własności leżące u podstaw relacji przyczynowych, o których mówi Worrall, za argument na rzecz realności przedmiotów, którym się je przypisuje. Przypisywane przedmiotom teoretycznym własności dzieli na własności detekcyjne i pomocnicze i twierdzi, że własności detekcyjne są bezpośrednio powiązane z doświadczeniem i służą do empirycznej interpretacji równań matematycznych. Własności pomocnicze natomiast odgrywają rolę heurystyczną w teoretycznym wyjaśnianiu zjawisk i nie są konieczne ze względu na odkrywane prawidłowości obserwowanych zjawisk. Mogą one być odrzucone w przyszłych teoriach lub stać się własnościami detekcyjnymi. Własności detekcyjne niezbędne do minimalnej interpretacji równań matematycznych stanowią wiedzę na temat obiektów generujących struktury relacyjne wskazywane przez Worralla.

Worrall i Chakravartty, uwzględniając fakt zmiany teorii w nauce, dowodzą, że prawdziwe są nie całe teorie, a tylko ich wybrane elementy, bezpośrednio powiązane z sukcesem predykcyjnym tych teorii. W przeciwieństwie do realizmu naukowego realizm strukturalny ogranicza poznawczą treść teorii naukowych do ich struktury matematycznej wraz z ich empirycznymi konsekwencjami. Różni się jednak od instrumentalizmu tym, że sugeruje, iż matematyczna

37 I. Hacking, Eksperymentowanie a realizm naukowy, tłum. z ang. D. Sobczyńska, w: Spór o realizm naukowy, dz. cyt., 29-65 
struktura teorii rzeczywiście odzwierciedla strukturę świata (tj. odzwierciedla rzeczywiste relacje między nieobserwowalnymi przedmiotami).

Chakravartty natomiast wiąże z realnością pewnych relacji przyczynowych realność przedmiotów konstytuujących te relacje. Semirealizm przyjmuje realność przedmiotów stanowiących minimalną interpretację teorii, tzn. takich, na które wskazują ich własności detekcyjne bezpośrednio występujące w równaniach odpowiedzialnych za sukces teorii. Odrzuca jednak realność obiektów takich, jakimi przedstawiają je teorie, ograniczając przedmioty do wiązki własności detekcyjnych. Jest jednak kwestią otwartą, na ile wiązka własności detekcyjnych wykracza poza przedmiot obserwacyjny oraz w jakim stopniu zleży ona od teorii.

Konsekwencje zarówno realizmu, jak i semirealizmu odnośnie do realistycznego wyjaśnienia zmian teorii w nauce, w szczególności zmiany teorii Fresnela na teorię Maxwella w optyce, budzą jednak pewne wątpliwości. Zdaniem Worralla eter nie narusza aproksymacyjnej prawdziwości teorii Fresnela, ponieważ nie jest reprezentowany w jej matematycznym formalizmie. Natomiast zdaniem Chakravartty'ego, nie należy on do minimalnej interpretacji teorii. Pozwala im to uznać teorię Fresnela za aproksymacyjnie prawdziwą teorię światła. Taka konkluzja budzi zastrzeżenia i wymaga dopowiedzenia, w jakim sensie i w jakim zakresie teoria Fresnela może być uznana za aproksymacyjnie prawdziwą. Rozwój fizyki odrzucił teorię światła jako drgań eteru za fałszywą, akceptując jednak falową naturę światła. Problem ten jest wciąż przedmiotem ożywionej dyskusji3i

38 Por. np. J. Saatsi, Reconsidering the Fresnel-Maxwell theory shift: how the realist can have her cake and EAT it too, Studies in History and Philosophy of Science 36(2005)3, 509-538 


\section{TRUDNOŚCI REALIZMU STRUKTURALNEGO I KIERUNKI JEGO ROZWOJU}

$\mathrm{Na}$ jedną z łatwiej dostrzegalnych trudności odniesienia realizmu strukturalnego do obecnych dojrzałych teorii wskazuje Chakravartty. Jest nią konsekwencja w postaci możliwości poznania aproksymacyjnie prawdziwych elementów jednej teorii dopiero z perspektywy jej następczyni, są to bowiem te równania teorii, które zostają zachowane przy jej zmianie. Nie jest to jednak cały aparat matematyczny teorii. Np. w teorii Fresnela obok równań, które stały się częścią teorii Maxwella, było wiele matematycznych sformułowań praw dotyczących samego eteru i jego oddziaływania z materią. Wszystkie one zostały odrzucone jako fałszywe. Realizm strukturalny nie określa warunków, które w ramach danej teorii identyfikowałyby te elementy jej formalizmu matematycznego, które zostaną zachowane. Zdaniem Chakravartty'ego semirealizm oferuje takie kryterium. Jest nim ograniczenie się do równań opisujących związki między własnościami detekcyjnymi. Według Chakravartty’ego przedmioty wyposażone we własności należące do minimalnej interpretacji równań teorii pozostają w teorii następnej i zachowują swoje własności detekcyjne ${ }^{39}$.

Juha Saatsi twierdzi jednak, że semirealizm, choć słusznie różnicuje własności detekcyjne i pomocnicze ze względu na ich konsekwencje dla realistycznej interpretacji obiektów teoretycznych, to zbyt powierzchownie ujmuje funkcję wyjaśniającą teorii i uwikłanie obu wyszczególnionych rodzajów własności w spełnianie tej funkcji. Np. w wypadku teorii Fresnela własności detekcyjne pozwalaja ustalić związki formalne rozchodzenia się fali, nie odzwierciedlają jednak natury rozchodzących się drgań. Tymczasem Fresnel w swoim wyprowadzeniu odwoływał się do tej natury, zakładając ciągłość energii i pędu w drganiach eteru. Odwoływał się także do nieobserwowalnych amplitud tych drgań i ich składowych, wiążąc

39 A. Chakravartty, Semirealism, dz. cyt., 404-405. 
je z natężeniem promienia świetlnego. Własności eteru pełniły więc zarówno heurystyczną, jak i wyjaśniająca funkcję w teorii Fresnela i nie sposób oddzielić ich od własności detekcyjnych w kontekście tej funkcji ${ }^{40}$.

Obok zasygnalizowanych powyżej trudności, stanowiących bezpośrednie konsekwencje przyjęcia tez realizmu strukturalnego, do których należy ograniczenie realistycznego traktowania postulowanych przez teorie przedmiotów (jak w wypadku realizmu strukturalnego Worralla) lub ograniczenie ich do wiązki własności detekcyjnych (jak w wypadku semirealizmu), można wskazać mniej bezpośrednie, lecz istotne z perspektywy realizmu naukowego konsekwencje ujęcia strukturalistycznego, do którego można zaliczyć oba stanowiska i ich odwołania do kumulatywizmu w roli kryterium aproksymacyjnej prawdziwości.

Odwołanie się do kumulatywizmu jako naczelnej podstawy dla określenia aproksymacyjnej prawdziwości teorii pociąga za sobą określone założenia i w konsekwencji zmienia koncepcję prawdy, do jakiej tradycyjnie odwołuje się realizm naukowy (epistemologiczny). Idea kumulatywizmu leży u podstaw strategii divide et impera, zgodnie z którą części teorii związane $\mathrm{z}$ sukcesem teorii są zachowane w jej następczyni ze względu na ich aproksymacyjną prawdziwość. Trudnością tego stanowiska jest nie tylko fakt, że aproksymacyjnie prawdziwe fragmenty teorii zostaną rozpoznane i wyodrębnione dopiero, gdy zostanie ona zastąpiona nową. Ważniejsze wątpliwości budzi założenie, że zachowanie części starej teorii w jej następczyni staje się kryterium prawdziwości tej pierwszej. Zatem nie relacja pomiędzy teorią i rzeczywistością, a relacja pomiędzy teorią i jej następczynią jest podstawą uznania jej za aproksymacyjnie prawdziwą. Jest to zastąpienie klasycznego rozumienia prawdy koncepcją prawdy relatywnej, polegającej na zgodności części teorii z inną, następującą

40 J. Saatsi, Reconsidering the Fresnel-Maxwell theory shift: how the realist can have her cake and EAT it too, dz. cyt., 517-520. 
po niej teorią. U podstaw tej relatywizacji leży założenie, że aproksymacyjnie prawdziwe części teorii mają być zachowane w kolejnej teorii, również aproksymacyjnie prawdziwej. Dopóki jednak nie możemy przypisać aproksymacyjnej prawdziwości obecnym teoriom (co, zgodnie $\mathrm{z}$ takim rozumieniem, można uczynić dopiero z perspektywy nieznanych dziś kolejnych teorii), to nie możemy także określić aproksymacyjnej prawdziwości ich poprzedniczek. Nie następuje porównanie przeszłej teorii z obecną teorią, która jest aproksymacyjnie prawdziwa, lecz z obecną teorią o nieznanej wartości logicznej. Sam kumulatywizm, o którym założono, że jest wynikiem prawdziwości części teorii, nie jest jej warunkiem wystarczającym. Klasyczne rozumienie prawdy odsyła do relacji teorii i zjawisk, niezależnie od jej stosunku do innych teorii. Konieczne jest poszerzenie stanowiska realistycznego o koncepcję aproksymacyjnej prawdziwości wolną od takiego relatywizmu.

Dalsze istotne trudności obu stanowisk związane są z podstawowym dla nich strukturalistycznym (semantycznym) ujęciem teorii naukowych ${ }^{41}$. Zakładając, że równania matematyczne reprezentują strukturę świata, Worrall nie wyjaśnia, jak jest możliwe reprezentowanie świata w strukturach matematycznych. Według van Frassena jest to podstawowe wyzwanie dla realizmu strukturalnego ${ }^{42}$.

Realizm strukturalny przyjmuje semantyczne ujęcie teorii naukowych, zgodnie z którym teorie są równoważne rodzinie modeli, będących abstrakcyjnymi strukturami (np. matematycznymi), w których spełnione są aksjomaty teorii. W wypadku teorii empirycznych,

41 Podejście takie spośród omawianych autorów przyjmują np. J. Worrall, A. Chakravartty i B. van Fraassen. Według tego podejścia teoria naukowa jest w pierwszej kolejności identyfikowana z rodziną modeli w sensie struktur matematycznych, za pomocą których reprezentowana jest dziedzina zjawisk, będąca jej przedmiotem. Szersze omówienie np. w: F. Suppe, The Semantic Conception of Theories and Scientific Realism, Urbana 1989, jak również w: A. Grobler, Metodologia nauk, Kraków 2008, 178-191.

42 B. van Frassen, Representation: The problem for Structuralism, Philosophy of Science 73(2006)5, 536-547. 
matematyczne modele teorii reprezentują zjawiska empiryczne. Przyjmowane w tym podejściu pojęcie reprezentacji jako odzwierciedlania struktur rzeczywistości w strukturze zjawisk w sensie izomorficznego odwzorowania pomiędzy strukturami niesie trudności związane z określeniem struktury zjawisk. Realistyczna interpretacja/koncepcja reprezentacji zjawisk w strukturach matematycznych jest niezbędnym uzupełnieniem realizmu strukturalnego. Jak zauważa Psillos, realizm strukturalny potrzebuje niezależnego argumentu, że równania matematyczne reprezentują strukturę świata. Dopiero wtedy ich zachowanie w nowej teorii daje uzasadnienie, że zastąpiona teoria reprezentowała tę strukturę poprawnie ${ }^{43}$. Poszukiwanie związku równań matematycznych z reprezentowaną rzeczywistością zjawisk prowadzi do wyłonienia pośrednika pomiędzy równaniami matematycznymi i strukturą zjawiska w postaci modelu danych. Przyjęcie ciągu reprezentacji, gdzie równania teorii (model matematyczny) reprezentują model danych (również matematyczny), a ten dopiero reprezentuje zjawiska, przenosi ciężar pytania o reprezentację rzeczywistości w równaniach matematycznych na wykazanie związku modelu danych $\mathrm{z}$ realnymi zjawiskami. Uzupełnienia o wyjaśnienia reprezentacji zjawisk w modelu danych potrzebuje zarówno realizm strukturalny, jak i semirealizm. Semirealizm, wprowadzając własności detekcyjne, pośrednio zakłada ich związek (lub tożsamość) $\mathrm{z}$ modelem danych. Pozostaje jednak do wyjaśnienia ich rola w reprezentacji świata w teorii naukowej. Bez uzupełnienia o teorię reprezentacji pozwalającą wyjaśnić związek teorii z realnymi zjawiskami, do których się ona odnosi, ani realizm strukturalny, ani semirealizm nie dają uzasadnienia realizmu naukowego wolnego od wątpliwości.

43 S. Psillos, Scientific Realism: How Science Tracks Truth, dz. cyt., 146. 


\section{ZAKOŃCZENIE}

Pytanie o możliwość obrony realizmu naukowego wobec dokonujących się w nauce zmian teorii, stanowiło oś powyższych rozważań. Zarówno próby formalnego podważenia lub osłabienia argumentu na rzecz realizmu naukowego, jak i próby uchylenia na takiej drodze zarzutu PI, odsłoniły potrzebę doprecyzowania sformułowań obu argumentów, nie przyczyniły się jednak do ostatecznego unieważnienia któregoś $\mathrm{z}$ nich.

Próby uzgodnienia stanowiska realistycznego $\mathrm{z}$ argumentem PI doprowadziły do znacznego zawężenia i osłabienia tez realizmu naukowego. Główne stanowiska, które formułują takie odpowiedzi, czyli realizm strukturalny (zapoczątkowany przez J. Worralla, a następnie rozwijany w wersji ontologicznej i epistemologicznej przez kolejnych autorów) oraz semirealizm Chakravartty'ego, choć dostarczają pewnej interpretacji zmiany teorii z perspektywy realizmu naukowego, to znacznie osłabiają jego główne tezy. Ograniczają aproksymacyjną prawdziwość teorii naukowych do ich części bezpośrednio związanych $\mathrm{z}$ sukcesem teorii i zachowanych $\mathrm{w}$ ich następczyniach. Realizm strukturalny dodatkowo ogranicza się tylko do struktur matematycznych teorii, uznając jej ontologię za niepoznawalną. Stanowi to odrzucenie tezy realizmu, że terminy teoretyczne dojrzałych teorii mają realne odniesienia. Zgodnie z realizmem strukturalnym nie mamy poznawczego dostępu do obiektów leżących u podstaw relacji tworzących te struktury. Semirealizm jest pod tym względem mniej restrykcyjny i interpretuje realistycznie istnienie „nośników” własności detekcyjnych, leżących u podstaw sformułowania prawidłowości matematycznych. Pozostawia jednak niewyjaśnioną kwestię związku przedmiotu wskazanego przez własności detekcyjne jednej teorii $\mathrm{z}$ realnym przedmiotem i jego tożsamości z przedmiotem wyznaczonym, na podstawie wartości detekcyjnych właściwych dla innej teorii. 
Inną ważną konsekwencją tych stanowisk jest rozumienie kluczowego pojęcia aproksymacyjnej prawdziwości teorii naukowych w sposób zrelatywizowany do kolejnych teorii, które zastępują je w rozwoju nauki.

Stanowiska będące główną obroną realizmu naukowego, przyczyniły się też do ograniczenia wersji realizmu naukowego, jaką był realizm konwergentny. Celem tego ograniczenia było zachowanie i obrona samej jego podstawy, głoszącej, że nauka w jakimś stopniu dociera poznawczo do realnego świata i część tej wiedzy bywa prawdziwa. Odsłaniają one jednak dalsze wyzwania, na jakie realizm naukowy musi odpowiedzieć. Do najważniejszych z nich należy problem reprezentacji zjawisk w strukturach matematycznych, jakimi są równania teorii i modele danych, oraz określenie aproksymacyjnej prawdziwości teorii naukowych, wolnej od relatywizmu względem innej teorii. O te kwestie zarówno realizm strukturalny, jak i semirealizm powinny być uzupełnione. Rozwinięcie tych problemów wymaga jednak odrębnego opracowania.

\section{BIBLIOGRAFIA}

Boyd R.N., On the Current Status of the Issue of Scientific Realism, Erkenntnis 19(1983)1-3, 45-90.

Chakravartty A., Semirealism, Studies in History and Philosophy of Sciences 29(1998)3, 391-408.

Chakravartty A., Truth and Representation in Science: Two Inspirations from Art, w: Beyond Mimesis and Convention: Representation in Art and Science, red. R. Frigg, M. Hunter, Springer, Dordrecht 2010, 33-50.

Doppelt G., From Standard Scientific Realism and Structural Realism to Best Current Theory Realism, Journal for General Philosophy of Science 42(2011)2, 295-316. Fahrbach L., How the Growth of Science Ends Theory Change, Synthese 180(2011)2, 139-155.

Grobler A., Metodologia nauk, Wydawnictwo Aureus - Wydawnictwo Znak, Kraków 2008.

Grobler A., Prawda a względność, Wydawnictwo Aureus, Kraków 2000. 
Hacking I., Eksperymentowanie a realizm naukowy, tłum. z ang. D. Sobczyńska, w: Spór o realizm naukowy, red. M. Kotowski, Oficyna Naukowa PFF, Wroclaw, 29-65.

Howson C., Exhuming the No Miracles Argument, Analysis 73(2013)2, 205-211.

Howson, C., Hume's Problem: Induction and the Justification of Belief, The Clarendon Press, Oxford 2000.

Jodkowski K., Teza o nierwspótmierności w ujęciu Thomasa Kubna i Paula Feyerabenda, Wydawnictwo UMCS, Lublin 1984.

Kotowski M., O rozwoju realizmu naukowego jako selektywnego sceptycyzmu, Filozofia Nauki 22(2014)3, 105-123.

Kotowski M., Realizm zreformowany. Filozofia Iana Hackinga a spór o status poznawczy wiedzy naukowej, Oficyna Naukowa PFF, Wrocław 2016.

Kuhn T.S., Struktura rewolucji naukowych, tłum. z ang. H. Ostromęcka, Fundacja Aletheia, Warszawa 2001.

Laudan L., Obalenie realizmu konwergentnego, tłum. z ang. M. Kotowski w: Spór o realizm naukowy, red. M. Kotowski, Oficyna Naukowa PFF, Wrocław 2018, 29-65.

Lyons D.T., Four Challenges to Epistemic Scientific Realism - and the Socratic Alternative, Spontaneous Generations: A Journal for the History and Philosophy of Science 9(2018)1, 146-150.

Musgrave A., Ostateczny argument za realizmem naukowym, tłum. $\mathrm{z}$ ang. M. Kotowski, w: Spór o realizm naukowy, red. M. Kotowski, Oficyna Naukowa PFF, Wrocław 2018, 89-116.

Park S., On Treating Past and Present Scientific Theories Differently, Kriterion 31(2017)1, 63-76.

Post H., Correspondence, invariance and heuristics, Studies in History and Philosophy of Science 2(1971)3, 213-255.

Psillos S., Knowing the Structure of Nature, Palgrave McMillan, New York 2009.

Psillos S., Scientific Realism: How Science Tracks Truth, Routledge, London 1999.

Putnam H., What is Mathematical Truth?, w: Mathematics, Matter and Method, Collected Papers, Vol. 2, Cambridge University Press, Cambridge1975, 60-78.

Saatsi J., Grasping at Realist Straws, Metascience 18(2009)3, 355-362.

Saatsi J., Reconsidering the Fresnel-Maxwell theory shift: how the realist can have her cake and EAT it too, Studies in History and Philosophy of Science 36(2005)3, 509-538.

Stanford P.K., Catastrophism, Uniformitarianism, and a Scientific Realism Debate. That Makes a Difference, Philosophy of Science 82(2015)5, 867-878. 
Suppe F., The Semantic Conception of Theories and Scientific Realism, University of Illinois Press, Urbana 1989.

Van Fraassen B.C., The Scientific Image, Oxford University Press, Oxford 1980.

Van Frassen B.C., Representation: The problem for Structuralism, Philosophy of Science 73(2006)5, 536-547.

Vickers P., Understanding the Selective Realist Defence Against the PMI, Synthese 194(2017)9, 3221-3232.

Worrall J., Miracles and Models: Why Reports of the Death of Structural Realism May Be Exaggerated, Royal Institute of Philosophy Supplements 61(2007)10, 125-154.

Worrall J., Realizm strukturalny. To co najlepsze z dwóch światórw, tłum. $\mathrm{z}$ ang. M. Kotowski w: Spór o realizm naukowy, red. M. Kotowski, Oficyna Naukowa PFF, Wrocław 2018, 145-175.

Wray K.B., Pessimistic Induction and the Exponential Growth of Science Reassessed, Synthese 190(2013)18, 4321-4330.

\section{SCIENTIFIC REALISM AND THEORY CHANGE IN SCIENCE}

Abstract. An important part of the contemporary dispute between scientific realism and anti-realism is an attempt to give a realistic interpretation to the historical facts of the theory change in science. According to L. Laudan, this fact undermines not only the most important argument for scientific realism but also the most important theses of this position. The argument contested by Laudan is the $\mathrm{H}$. Putnam's claim that the huge success of science in predicting novel phenomena and developing new technologies proves at least the approximate truth of scientific theories. Laudan, however, shows facts from the history of science when successful theories have turned out to be false over time. A related argument against realism called Pessimistic Induction (PI). According to $\mathrm{PI}$, since previous theories that had been successful turned out to be false from the perspective of newer ones, also current successful theories may turn out to be false in the future. This undermines the thesis that the predictive success of a theory is related to its approximate truthfulness. Therefore, an important challenge for scientific realism is to reconcile its theses with the facts of theory change in science. The most significant solutions to this problem are provided by structural realism proposed by J. Worrall and semirealism by A. Chakrawartty. Both positions adopt the same strategy of defending realism known as divide et impera, stating that not all theories, but only parts of them that are directly related to success, meet the theses of realism. Scientific realism in these formulations is largely limited and weakened. The aim of the article is to present these solutions and show, on the one hand, realistic answers to the PI argument provided by these positions, and on the other hand, the limitations that result from them for scientific realism. The weakened version of realism they propose is also not free from significant difficulties to which both 
structural realism and semirealism must respond. The identification of these difficulties may be helpful for the further development of the realistic position.

Keywords: scientific realism; convergent realism; structural realism; semirealism; approximate truth; divide et impera strategy

Janina Buczkowska

Uniwersytet Kardynała Stefana Wyszyńskiego w Warszawie, Instytut Filozofii

(Cardinal Stefan Wyszyński University in Warsaw, Institute of Philosophy, Poland)

ORCID: https://orcid.org/0000-0001-5387-2310

janina.buczkowska@uksw.edu.pl

DOI: 10.21697/spch.2020.56.3.01 